\title{
Spatial Patterns of Water and Nitrogen Response Within Corn Production Fields
}

\author{
Jerry L. Hatfield \\ National Laboratory for Agriculture and the Environment \\ USA
}

\section{Introduction}

Agricultures role on environmental quality has been debated for many decades and although there has been advances in our understanding of the linkage between agricultural management and environmental quality, there is still much we don't understand about the combination of field-scale and watershed scale management changes (Hatfield et al., 2009). There is increasing interest in developing solutions to environmental quality problems originating from agricultural management; however, the challenge remains on how we integrate the pieces of a very complex puzzle together to achieve solutions which transcend space and time scale. Within the Midwestern United States, the reoccurrence of the hypoxic zone within the Gulf of Mexico and the large increase in the size of the hypoxic zone after the 1993 floods in the Midwest focused attention on the role of agriculture in nonpoint source pollution. Burkart and James (1999) evaluated the nitrogen $(\mathrm{N})$ balance for the Mississippi River Basin and concluded that mineralization of soil organic matter and application of commercial fertilizer was two primary contributors to $\mathrm{N}$ load. Jaynes et al. (1999) after examination of a small watershed (5400 ha) in central Iowa found that nitrate- $\mathrm{N}$ losses averaged $20 \mathrm{~kg} \mathrm{ha}^{-1}$ for this watershed and reached a level in excess of $40 \mathrm{~kg} \mathrm{ha}^{-1}$ during 1993. Hatfield et al. (1998) found that drainage from Walnut Creek was the primary transport pathway for nitrate and the annual loads were related to precipitation differences among years. Hatfield et al. (1999) found that for Walnut Creek watershed that drainage through the subsurface drain lines accounted for approximately half of the annual precipitation with evapotranspiration accounting for the other half. This movement of water through the soil profile and the solubility of nitrate in water produce large amounts of nitrate-N loss (Jaynes et al, 1999). These results suggested a strong link between precipitation, crop water use patterns, and nitrate losses. Occurrence of the hypoxic zone has prompted an increased level of debate about the need to reduce $\mathrm{N}$ inputs into agricultural systems. Opponents of this conclusion argue that over the past 20 years the input of $\mathrm{N}$ fertilizer has not increased, soil organic matter levels haven't changed, and crop production levels have increased suggesting that the efficiency of the agronomic production system has increased and any change in nitrate loss would be difficult to achieve. Hatfield et al. (2009) performed an analysis of the temporal changes in the nitrate- $\mathrm{N}$ concentrations in the Raccoon River watershed in central Iowa and observed the changes in nitrate-N concentrations since the 1970's were dominated more by changes in land use practices 
than on nutrient management. This change in land use affected the soil water balance and the patterns of water movement within fields and throughout the season rather than application rates as the primary transport mechanism.

Crop yield response to $\mathrm{N}$ has been the focus of agronomic studies and has been primarily conducted on small plots under relatively controlled conditions. However, the advent of application systems to differentially apply $\mathrm{N}$ across fields has opened up new possibilities for quantifying $\mathrm{N}$ response at a scale which producers would have confidence of the information being applicable to their operations. Understanding field scale responses to $\mathrm{N}$ management practices is critical to the development of precision agriculture tools and methods for determining the patterns to change application rates within a field. One method that has been applied to the precision application of $\mathrm{N}$ has been to use leaf color or reflectance as a measure of $\mathrm{N}$ status. Detection of $\mathrm{N}$ stress in crop plants using leaf color has created opportunities for field-scale evaluation of $\mathrm{N}$ response. Some of the methods that have been employed are the Soil-Plant Analyses Development (SPAD) chlorophyll meter, color photography, or canopy reflectance factors to assess $\mathrm{N}$ variation across corn fields (Schepers et al. 1992, 1996; Blackmer et al. 1993, 1994, 1996a, 1996b; Blackmer and Schepers, 1996). These methods have been based on comparisons of an adequately-fertilized strip in the same field with a strip with an altered $\mathrm{N}$ rate. This approach eliminates the requirements for prior knowledge of the relationship between nutrient concentration and crop reflectance.

There have continued to be advances in the use of remote sensing methods to estimate $\mathrm{N}$ status in crops. Lee et al. (2008) used a single waveband at $0.735 \mu \mathrm{m}$ to quantify $\mathrm{N}$ status in rice (Oryza sativa L.). In their method they used the first derivative of the reflectance at $0.735 \mu \mathrm{m}$ as difference of the reflectance at $0.74-0.73 \mu \mathrm{m}$ and dividing by ten. They found this to be as accurate as other indices including the normalized difference vegetative index (NDVI) expressed as $\left(R_{N I R}-R_{R E D}\right) /\left(R_{N I R}-R_{R E D}\right)$ where $R_{N I R}$ reflectance in the nearinfrared waveband $(0.78-0.79 \mu \mathrm{m})$ and $R_{\text {RED }}$ the reflectance in the $0.61-0.68 \mu \mathrm{m}$ waveband. They also compared a simple ratio vegetative index expressed as $R_{N I R} / R_{R E D}$. They used these wavelengths to create maps of canopy $N$ status across fields at the panicle formation stage. They showed the variation in canopy $\mathrm{N}$ status but didn't evaluate the spatial patterns within fields. There continues to be advancements in the use of remote sensing to detect $\mathrm{N}$ status in crops, Chen et al. (2010) developed a double-peak canopy N index to predict plant $\mathrm{N}$ concentration in both corn (Zea mays L.) and wheat (Triticum aestivum L.) and found this worked well for N status; however, did not extend this approach to assess field variation. This is an extension of an earlier method proposed by Haboudane et al. (2002) in which they proposed leaf chlorophyll indices could be used to predict leaf chlorophyll content for application to precision agriculture. One of the lingering questions that remain is the degree of variation present in $\mathrm{N}$ response across a corn production field.

Spatial variation of crop yield across fields has prompted a series of questions about the role of nutrient management. Jaynes and Colvin (1997) showed that yield variation within central Iowa fields was related to precipitation differences among years. However, in their study there was not a measure of crop water use within the field with the implied assumption that precipitation was uniform across the field. Hatfield and Prueger (2001) and Hatfield et al. (2007) found a large amount of spatial variation in water use across fields 
related to soil types and $\mathrm{N}$ management. These results have prompted a series of studies developed to further elucidate these interactions. Studies conducted on water use and $\mathrm{N}$ application has been done within a single soil type or management zone. There is a lack of information on the interactions among soil, crop water use, and $\mathrm{N}$ management that would help develop an understanding of better $\mathrm{N}$ management in cropping systems typical of the Midwest United States. The increasing concern about the role of agricultural practices on water quality have prompted us to ask a series of questions about the interactions between crop water use, $\mathrm{N}$ use, yield, and soils. The objectives of our studies have been to quantify the interactions among $\mathrm{N}$ application, crop water use, yield, and soils for central Iowa production fields on the Clarion-Nicollet-Webster soil association and to determine the impact of these interactions on $\mathrm{N}$ management and potential offsite impacts from drained agricultural lands.

Spatial analysis of field scale changes have recently been evaluated by Inman et al. (2008). They determined the relationship between early season NDVI, soil color-based management zones, and relative corn yields. Values of NDVI were collected at the eight-leaf growth stage and regression models explained between 25 to $82 \%$ of the variability in relative yield where relative yield was defined as the ratio of the observed yield to the maximum yield for the field as defined by Brouder et al. (2000). Inman et al. (2008) found coupling NDVI with the color-based soil zones didn't increase the ability to explain yield within the field. A complimentary study conducted by Massey et al. (2008) on ten years of site-specific data for corn, soybean (Glycine max (L.) Merr.), and grain sorghum (Sorghum bicolor L.) for a 36.5 ha field in central Missouri with claypan soils to quantify temporal changes in crop yield response. They developed profitability maps for the field and found that large areas of the field had negative profit due to areas of the field in which there was significant topsoil erosion. Brock et al. (2005) showed that high yielding management zones in a corn-soybean rotation were associated with poorly drained level soils while low yielding zones were associated with eroded or more sloping soils. Sadler et al. (2000a and 2000b) conducted a field scale study on drought stressed corn and found that although there was a relationship between soil map units and grain yield these relationships did not explain the reason for the yield variation. They found that variation among sites within soils was significant and suggested that improved understanding of yield variation would require more attention to within season observations of crop water stress. These studies have shown that there is a large amount of variation present within fields and that our understanding of the reasons for these patterns of variation would improve the knowledge base for precision agriculture applications.

There have been several studies that have related remote sensing indices to crop yield and detection of $\mathrm{N}$ status in plant leaves; however, there has been little research on the spatial patterns within the field that could lead to improved understanding of the changes that occur within the growing season. There is a lack of understanding of the interactions between the spatial patterns of crop water use and $\mathrm{N}$ response. This study was conducted to evaluate the spatial and temporal patterns of crop water use and couple these observations with observations collected from $\mathrm{N}$ strips within fields as part of a $\mathrm{N}$ evaluation study. The objective of this study was to evaluate the spatial patterns within different fields observed by remote sensing and yield maps collected at harvest with yield monitors to determine the information content contained in spatial analyses of agricultural fields. 


\section{Methodological approach}

\subsection{Water-nitrogen interaction studies}

Studies have been conducted in the Clarion-Nicollet-Webster Soil Association in central Iowa within the Walnut Creek watershed. This 5400 ha watershed was described in Hatfield et al. (1999). Production sized fields have been used as experimental units for these studies because of the need to quantify the effects of different $\mathrm{N}$ rates on crop yield and water use across soil types. These production fields ranged in size from 32 to 96 ha each with a similar experimental design. The experimental design was a replicated plot design with strips of different $\mathrm{N}$ rates being a treatment and each treatment replicated at least three times across a field. Nitrogen rates were applied in 1997 and 1998 using a starter application at planting of $50 \mathrm{~kg} \mathrm{ha}^{-1}$ only with the second treatment having the $\mathrm{N}$ starter rate and the sidedress rate determined by the Late Spring Nitrate Test (LSNT). The third treatment was the starter plus a sidedress rate to represent a non-limiting $\mathrm{N}$ rate of an additional $150 \mathrm{~kg} \mathrm{ha}^{-1}$. This experimental procedure was described by Jaynes et al. (2001). In 1999 and 2000, the N application procedure was modified to further refine $\mathrm{N}$ application rates based on the use of the leaf chlorophyll measurements and soil test based on the results obtained from the 1997 and 1998 experiments. The rates applied were 50, 100, and $150 \mathrm{~kg} \mathrm{ha}^{-1}$ to different soils, planting rates, and plant population densities $\left(75,000\right.$ and 85,000 plants ha- $\left.{ }^{-1}\right)$. Nitrogen rates were applied uniformly across each field using liquid UAN $(32 \% \mathrm{~N})$ for these studies. These applications were applied with production scale equipment to mimic producer operations.

Soil $\mathrm{N}$ concentrations were measured prior to spring operations, after planting, and at the end of the growing season after harvest to a soil depth of $1.5 \mathrm{~m}$ using a $5 \mathrm{~cm}$ core. Cores were subdivided into depth increments to estimate the $\mathrm{N}$ availability throughout the root zone. Sample position was recorded with a GPS unit to ensure accurate location of each subsequent sample. Nominal plot size for plant measurements and yield determinations was $15 \times 15 \mathrm{~m}$. Yields were measured on $5 \mathrm{~m}$ length of row for five subsamples within each plot in which no plants had been removed or measured during the growing season. Plots were replicated three times within each treatment.

Crop water use rate was measured from planting to harvest with an energy balance method (Bowen ratio in 1997 and 1998, and eddy correlation in 1999 and 2000). These units consisted of a net radiometer positioned at $3 \mathrm{~m}$ above the canopy, soil heat flux at $10 \mathrm{~cm}$ (within the row, middle of the row, and adjacent to the row), wind speed, air temperature, water vapor pressure (positioned at 0.5 and $1.5 \mathrm{~m}$ above the canopy), three dimensional sonic anemometer and krypton hygrometer (positioned at $1 \mathrm{~m}$ above the canopy), and an infrared thermometer ( $15^{\circ}$ fov) positioned at $45^{\circ}$ from nadir in a south-facing direction. All measurements were recorded at 10-second intervals and either 15 minute or 30 minute averages stored in the data acquisition unit. Data were screened to ensure proper data quality and then converted to equivalent water depth and summed for the growing season to determine crop water use. Within each soil-N combination we had a single energy balance station and this measurement technique provides a sample representative of a $50 \mathrm{~m}^{2}$ area. These instruments were positioned to provide a measurement of the representative area around the plant measurements. Missing data for a given station were treated by using the relationships among instruments within a soil type across $\mathrm{N}$ management practices to determine the relationships among variables. These relationships were then used to fit in 
any missing data using an approach similar to the method described by Hernandez-Ramirez (2010). Generally the length of any missing data was less than 3 hours. The amount of missing data for these experiments was less than $3 \%$ of the total data record.

Crop transpiration rates were estimated from an energy balance model that determined the soil water evaporation rate based on the leaf area index of the crop and previous precipitation amounts following the approach described by Ritchie and Burnett (1971). Soil water evaporation rates were estimated from a surface energy balance model based on crop residue cover amounts and the energy balance. Precipitation for these studies was available from a tipping bucket raingauge located at a meteorological station within $1 \mathrm{~km}$ of the field sites.

Crop growth and development were measured in a variety of ways. In 1997 measurements were made of yield at harvest. Beginning in 1998 and 1999, a more intensive plant regime of weekly plant measurements consisting of leaf area, phenological stage, number of leaves, dry weight, and plant height were made on 10 plants from each plot and each plot was replicated three times. In 2000, the frequency was decreased to four destructive plant samplings to represent the 6-leaf stage, 12-leaf stage, tasseling, and mid-grain fill. Leaf chlorophyll measurements were made on 30 plants in each plot with a leaf chlorophyll meter at two times per week commencing with the 6 leaf stage and continuing through late grain fill. The upper leaf was measured at the mid-leaf position until the tassel appeared then the leaf immediately above the ear position was measured. Leaf carbon and $\mathrm{N}$ contents were determined on dry, ground samples from same stages as the 2000 plant samples were collected. For 1999 and 2000 experiments, stalk sugar content was measured with a refractive method using sap collected from freshly cut stalks. This was done on ten plants from each plot. Grain quality parameters of protein, oil, and starch were measured on subsamples of grain collected from the hand-harvest samples. Field yields were measured with yield-monitors mounted on the producers combine. These data were registered with a GPS unit to obtain field locations.

Data analyses for these studies are based on crop yield, total seasonal water use, and $\mathrm{N}$ application. Water use and $\mathrm{N}$ use efficiency was determined by the ratio of crop yield to either seasonal crop transpiration or $\mathrm{N}$ application rates. Intensive plant sampling data are not described in this report but were used to understand the dynamics of plant response to changes in within season $\mathrm{N}$ management decisions. Likewise, the leaf chlorophyll and stalk sugar content data were used to guide decisions in the 1999 and 2000 experiments. These data sets represent a complete analysis of crop-soil-water-N interactions.

\subsection{Spatial nitrogen studies}

Experiments were conducted in 12 different fields located in central Iowa from 2000 to 2002 (Table 1). These fields varied in size from 15 to 130 ha. Each of the field experiments was similar with strips arranged in the field with different $\mathrm{N}$ rates and in three of the study fields, variable planting rates were also used as a treatment variable. The strips were a minimum of $50 \mathrm{~m}$ wide covering at least 60 rows of corn. The arrangement of the $\mathrm{N}$ treatments was randomized across the field and strips were treated as replicates. Nitrogen was applied as UAN (Urea and Ammonium Nitrate) as a preplant treatment in all fields and incorporated into the soil. Rates of $\mathrm{N}$ application were determined by using 
soil test records from the producer's fields to determine the typical rate applied and then using 0.5 and 1.5 times that rate in the other strips. All production practices were conducted by the producer during the course of the experiment. In one experiment, planting rates were evaluated and randomly assigned as blocks across the field with $\mathrm{N}$ rates as subplots within a block. Planting rates were also randomized across the field. In each field the same corn hybrid was planted; however, hybrids varied among fields and years. For each field there were overlays of soil type, elevation collected from Real Time Kinetic GPS equipment to create $1 \mathrm{~m}$ contours, and $\mathrm{N}$ application rate. Soils within fields were a mixture of Canisteo (Fine-loamy, mixed (calcareous), mesic Typic Haplaquolls), Clarion (Fine-loamy, mixed, mesic Typic Hapludolls), Nicollett (Fine-loamy, mixed, mesic Aquic Hapludolls), Okoboji (Fine, montmorillonitic, mesic Cumulic Haplaquolls), and Webster (Fine-loamy, mixed, mesic Typic Haplaquolls) soils. An example of the field layout for this experiment is shown in Fig. 1.

\section{Nitrogen Study 2002}

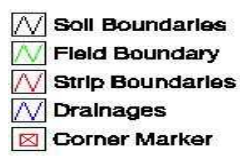

Field: Calhoun East (Ferguson)

T86N R31W Section 32

UTM, Zone 15, meters, NAD83

Q Corner Marker

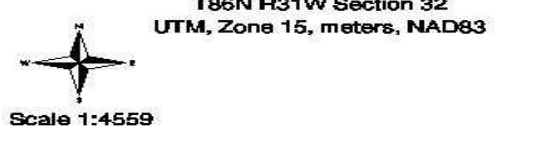

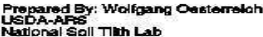
Amberal Lall Thith Lab

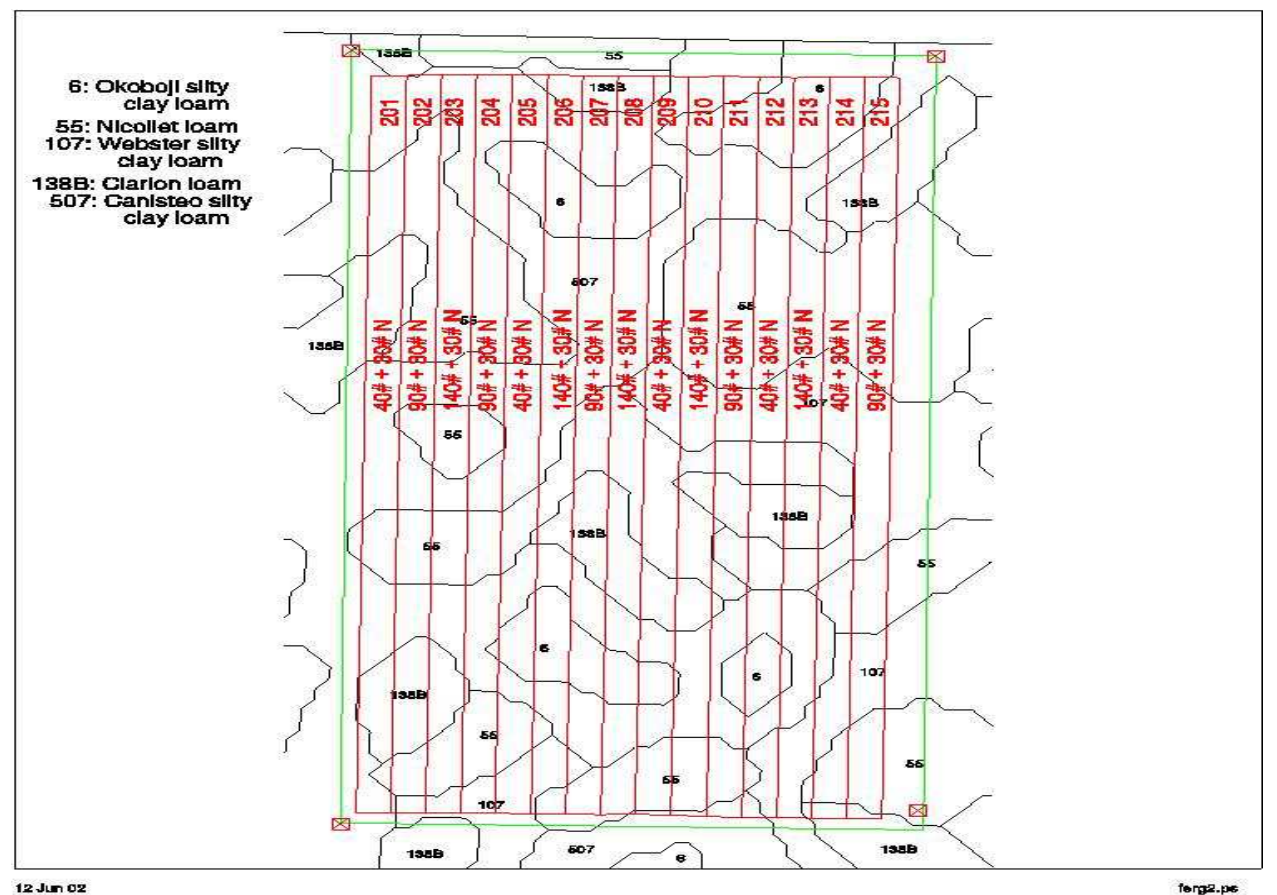

Fig. 1. Experimental layout for field-scale $\mathrm{N}$ management study conducted across central Iowa from 1999 to 2002. 


\begin{tabular}{|c|c|c|}
\hline Year/Field & Nitrogen Rate (kg/ha) & Agronomic Variables \\
\hline $2000 /$ Carroll 1 & $70,116,162,210$ & 72,000 plants/ha \\
\hline $2000 /$ Carroll 2 & $70,116,162,210$ & 72,000 plants/ha \\
\hline 2000/Sac & $70,116,162,210$ & 72,000 plants/ha \\
\hline 2000/Shelby & $70,116,162,210$ & 72,000 plants/ha \\
\hline 2000/Story 1 & $52,100,145$ & 72,000 plants/ha \\
\hline 2000/Story 2 & $52,100,145,191$ & 72,000 plants/ha \\
\hline 2001/Story 1 & 133,180 & 75,000 plants/ha \\
\hline 2001/Story 2 & $51,102,144$ & 75,000 plants/ha \\
\hline 2000/Story 3 & $57,126,173$ & 79,000 plants/ha \\
\hline 2002/Calhoun East & $78,134,190$ & 79,000 plants/ha \\
\hline 2002/Dallas South & $78,134,190$ & $57,000,69,200,81,500$ plants/ha \\
\hline 2002/Coon Rapids & $67,134,201$ & \\
\hline
\end{tabular}

Table 1. Nitrogen rates and associated agronomic parameters for the field experiments from 2000 to 2002.

Soil map units were extracted from the soil survey data and detailed topographic data were collected with GPS equipment for each field. Soil nutrient content data were collected from each field for the upper $1 \mathrm{~m}$ of the profile for a minimum of 30 locations within each field prior to the growing season. Yield data were obtained from each field using yield monitors on the producers combine and these were calibrated prior to harvest. Yields were corrected to $15.5 \%$ grain moisture content.

Remote sensing observations for each field were obtained from an aircraft based hyperspectral unit with 35 wavebands (Table 2). Details on the wavebands and radiometric resolution are provided in Table 2 for each waveband. Data were obtained on clear days at four times during the growing season in May, July, August, and September. These times were selected to obtain data after planting and before there was sufficient growth to affect the soil background (May), maximum vegetative growth (July), mid-grain fill (August), and near physiological maturity (September). The pixel sizes were nominally $2 \times 2 \mathrm{~m}$ across the study sites. These data were collected with GPS signals to provide a location of each pixel and these were georeferenced to the yield data and other parameters collected from each field with a positional accuracy of $5 \mathrm{~m}$. All data were georeferenced and all data were aggregated into $8 \times 8 \mathrm{~m}$ pixels for further analysis. This size was selected because of the width of harvest equipment for the yield monitor data. 


\begin{tabular}{|l|c|c|c|c|c|c|c|c|}
\hline $\begin{array}{l}\text { Band } \\
\text { Number }\end{array}$ & $\begin{array}{c}\text { Center } \\
\text { Wavelength } \\
(\mu \mathrm{m})\end{array}$ & $\begin{array}{c}\text { Band } \\
\text { Width } \\
(\boldsymbol{\mu m})\end{array}$ & $\begin{array}{c}\text { Band } \\
\text { Number }\end{array}$ & $\begin{array}{c}\text { Center } \\
\text { Wavelength } \\
(\boldsymbol{\mu m})\end{array}$ & $\begin{array}{c}\text { Band } \\
\text { Width } \\
(\boldsymbol{\mu m})\end{array}$ & $\begin{array}{c}\text { Band } \\
\text { Numbe } \\
\mathbf{r}\end{array}$ & $\begin{array}{c}\text { Center } \\
\text { Wavelength } \\
(\boldsymbol{\mu m})\end{array}$ & $\begin{array}{c}\text { Band } \\
\text { Width } \\
(\boldsymbol{\mu m})\end{array}$ \\
\hline 1 & 0.426 & 0.003 & 13 & 0.681 & 0.006 & 25 & 0.797 & 0.006 \\
\hline 2 & 0.445 & 0.006 & 14 & 0.689 & 0.006 & 26 & 0.805 & 0.006 \\
\hline 3 & 0.506 & 0.006 & 15 & 0.698 & 0.006 & 27 & 0.819 & 0.005 \\
\hline 4 & 0.520 & 0.006 & 16 & 0.707 & 0.006 & 28 & 0.826 & 0.005 \\
\hline 5 & 0.530 & 0.006 & 17 & 0.715 & 0.006 & 29 & 0.833 & 0.005 \\
\hline 6 & 0.540 & 0.006 & 18 & 0.724 & 0.006 & 30 & 0.851 & 0.005 \\
\hline 7 & 0.549 & 0.006 & 19 & 0.734 & 0.006 & 31 & 0.860 & 0.006 \\
\hline 8 & 0.561 & 0.006 & 20 & 0.743 & 0.006 & 32 & 0.869 & 0.006 \\
\hline 9 & 0.580 & 0.006 & 21 & 0.755 & 0.006 & 33 & 0.880 & 0.006 \\
\hline 10 & 0.599 & 0.006 & 22 & 0.766 & 0.006 & 34 & 0.890 & 0.006 \\
\hline 11 & 0.620 & 0.006 & 23 & 0.774 & 0.006 & 35 & 0.899 & 0.006 \\
\hline 12 & 0.639 & 0.006 & 24 & 0.785 & 0.006 & & & \\
\hline
\end{tabular}

Table 2. Wavebands and bandwidth for the AISA hyperspectral data collected over the field sites in 2000 to 2002.

Data were analyzed on the individual $\mathrm{N}$ strips within the field and across the field. Vegetative indices were computed from the reflectance data obtained from the aircraft data and correlated to strip yield and field level yield observations. Correlation and regression analysis were conducted between $\mathrm{N}$ rate and corn yield for each individual field and across all fields for each year of the study. T-tests among means were conducted on differences between soils within a field strip while analysis of variance was conducted on $\mathrm{N}$ rates across a field with an interaction term based on the soil type by $\mathrm{N}$ rate comparison. These analyses were made using ANOVA and GLM models in SAS (SAS 2009). Spatial analysis was conducted for each field using GS+ version 5.1 to determine the spatial relationships among yield and the vegetative indices across different fields. Autocorrelation values were computed across the field using the field location points as coordinates to compute the range and sill for yield and the red/green index.

\section{Results and discussion}

\subsection{Spatial variation in soil water use}

Results from the studies where crop water use was quantified across the field revealed major differences among soil types. An example is shown in Fig. 2 for crop water use patterns for a Clarion and Webster soil with two different $\mathrm{N}$ rates. There was only a single meteorological unit in each soil type; however, error analysis for daily measurements are less than $10 \%$ of the daily total water use so the differences shown among soil types and $\mathrm{N}$ rates in Fig. 2 are significantly different at the end of the growing season. Crop water use patterns began to deviate shortly after crop establishment and continued throughout the growing season with the most noticeable difference occurring after Day of Year (DOY) 200 at the beginning of the grain-filling period (Fig. 2). The differences between the Clarion and Webster soil are due to their organic matter content with the Clarion soil having organic matter content between $1-2 \%$ and the Webster soil between $4-5 \%$. This leads to a difference 
in water holding capacity of nearly $100 \mathrm{~mm}$ in the upper $1 \mathrm{~m}$ for these two soil profiles. By extension, this creates a difference in the amount of soil water available to the growing crop during the season. In this comparison, Clarion soil with the lower amount of $\mathrm{N}$ applied showed the larger amount of crop water use during the season and ultimately showed the larger grain yield at the end of the growing season compared to high rates of $\mathrm{N}$ application. In typical growing seasons in central Iowa, there is adequate soil water available for plant growth early in the growing season and it is not until the onset of the reproductive period in which crop water use rates increase and precipitation amounts begin to diminish and to meet atmospheric demand there is a reliance on the amount of water stored within the soil profile.

A recent study by Hatfield et al. (2007) revealed large differences in the daily and seasonal amounts of crop water use across corn and soybean fields in central Iowa. They found the primary reasons for these differences were due spatial variation in precipitation and spatial variation in soils across various fields. These results confirm the observations collected from multiple soils within the same field. The observations collected from several different studies across multiple years reconfirm the observations shown in Fig. 2.

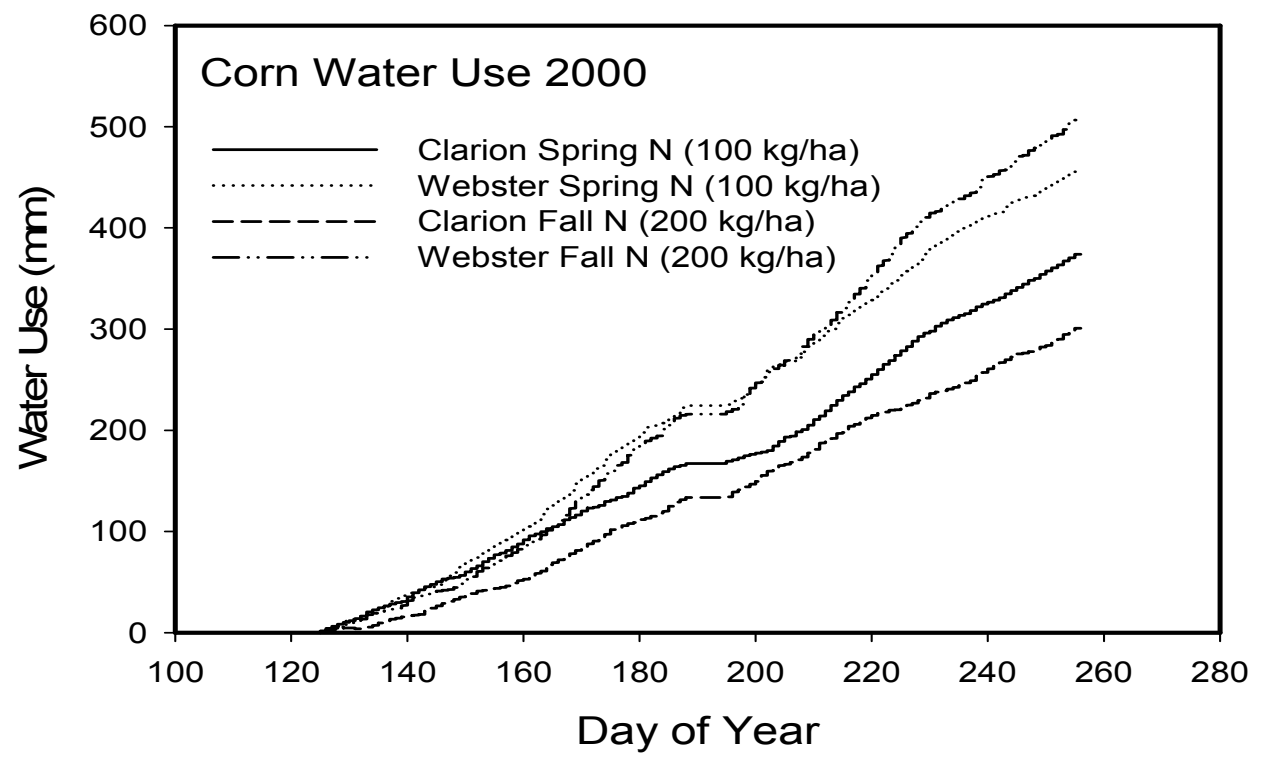

Fig. 2. Crop water use patterns during the 2000 growing season for corn on two soil types with two nitrogen application rates.

An extension beyond the crop water use patterns is the development of an assessment of water use efficiency. Water use efficiency is expressed as the amount of grain yield relative to the seasonal total of transpiration. In this case, transpiration was determined by removing the soil water evaporation component from the total crop water use amounts. In this analysis, water use efficiency was calculated for the $150 \mathrm{~kg} \mathrm{ha}^{-1} \mathrm{~N}$ application rate. What is 
striking in this figure is the observation that we have a large number of points which are below the line which can be interpreted as using water but not producing a large yield. Some of these are related to low $\mathrm{N}$ rates; however, others have large amounts of $\mathrm{N}$ (Fig. 3). The primary reason for this type of relationship is due to the seasonal pattern of crop water use (Fig. 2) which causes water deficit conditions in the grain-filling period. Water is the primary variable causing variation in corn yields more than $\mathrm{N}$ application rates. These observations prompted the extension of the $\mathrm{N}$ studies to be conducted across a production fields in central Iowa.

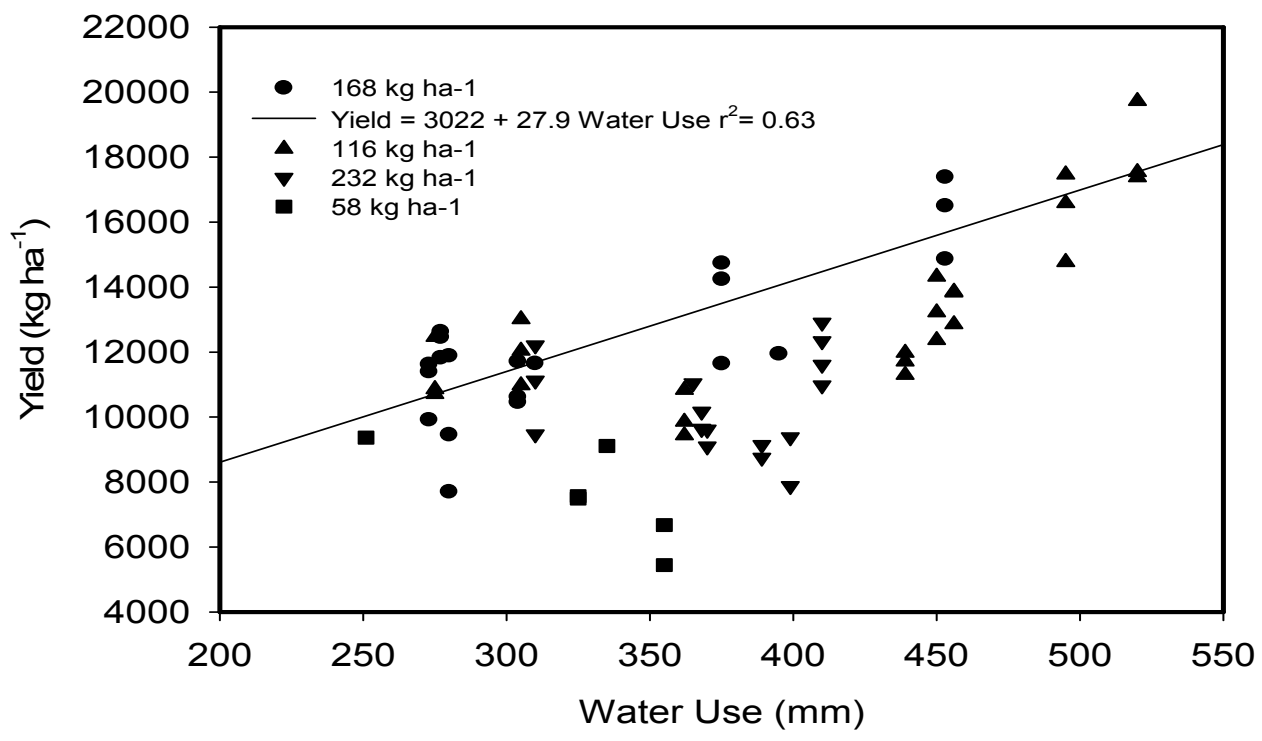

Fig. 3. Water use efficiency for corn for multiple years with different nitrogen application rates based on observation of seasonal totals of transpiration and grain yield.

\subsection{Field scale response to nitrogen}

Corn yield response to $\mathrm{N}$ applications varied across fields and years (Fig. 4). These data were separated by field and year to remove the potential confounding effects of weather variation among years. Analysis of the relationship between $\mathrm{N}$ rate and yield revealed that most fields showed no response to $\mathrm{N}$ (Table 3). The Sac Field 1 showed a negative response to $\mathrm{N}$ rate while the other fields showed a positive response to $\mathrm{N}$ (Table 3). The different response to $\mathrm{N}$ poses a problem in developing a general set of guidelines for $\mathrm{N}$ management and raises questions about why these fields differ in their yield response to $\mathrm{N}$ rate. However, this observation provides an opportunity for application of precision agricultural tools if the underlying mechanism for the difference can be identified and is consistent among growing seasons to allow for application of this information for decision-making. 

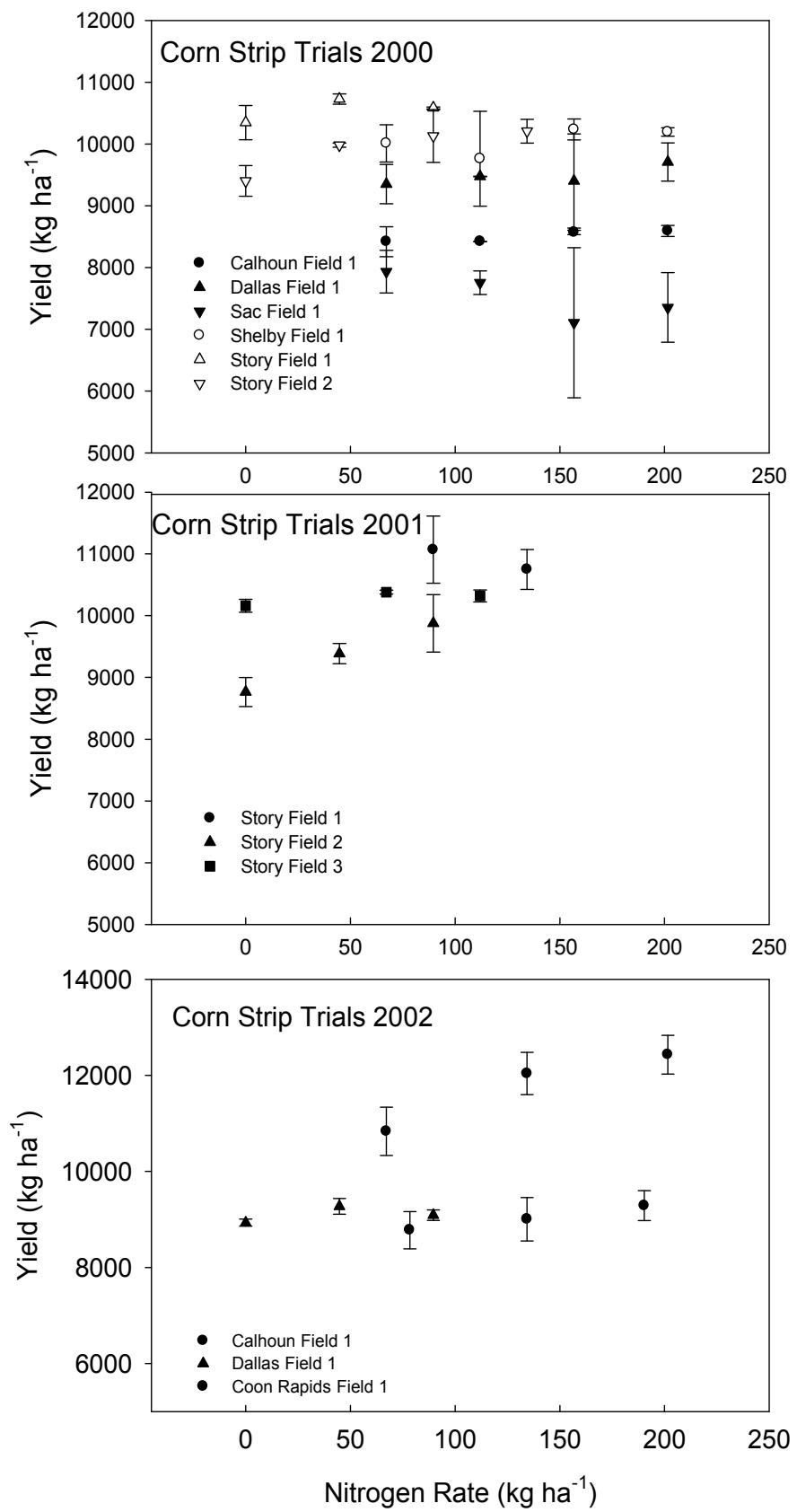

Fig. 4. Corn yield response to applied nitrogen in different fields in central Iowa from 2000 to 2002 . 


\begin{tabular}{|l|c|c|}
\hline Year/Field & Significance & Slope \\
\hline $2000 /$ Carroll 1 & ns & \\
\hline $2000 /$ Carroll 2 & ns & \\
\hline $2000 /$ Sac & ns & - \\
\hline $2000 /$ Shelby & ns & \\
\hline $2000 /$ Story 1 & $* *$ & + \\
\hline $2000 /$ Story 2 & ns & + \\
\hline $2001 /$ Story 1 & $* * *$ & + \\
\hline $2001 /$ Story 2 & $* *$ & + \\
\hline $2000 /$ Story 3 & $*$ & + \\
\hline $2002 /$ Calhoun East & ns & \\
\hline $2002 /$ Dallas South & $* *$ & \\
\hline $2002 /$ Coon Rapids & & \\
\hline
\end{tabular}

ns- Not significant, ${ }^{*}$-p $<0.1,{ }^{* *}$-p $<0.05,{ }^{* * *}$-p $<0.001$

Table 3. Analysis of the effect of nitrogen rates on corn yields from the fields in central Iowa.

There was a range of soils within these fields and across the study sites. Variation among strips within a field for a given $\mathrm{N}$ rate was not significant for all fields when evaluated with a simple analysis of variance (ANOVA) using like strips as replicates. Understanding that $\mathrm{N}$ response is not consistent among the different fields creates questions about reasons for $\mathrm{N}$ responses observed among fields. Development of processes for the application of $\mathrm{N}$ within a field that takes advantage of information about corn response to $\mathrm{N}$ would greatly enhance the efficiency of $\mathrm{N}$ use. To explore this question and the lack of a consistent response, further evaluations were conducted on the data set. An additional data set on $\mathrm{N}$ response across a single field obtained by Hatfield and Prueger (2001) showed that N response was related to soil water holding capacity (Fig. 5).

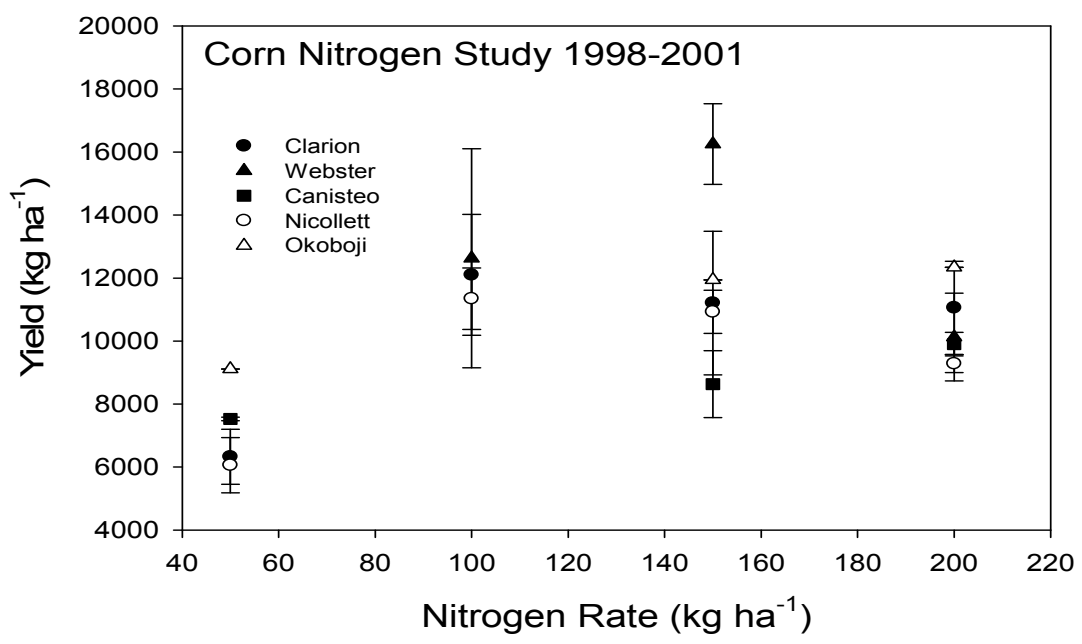

Fig. 5. Corn yield response to applied nitrogen across five different soils for a field in central Iowa for 1998 to 2001. 
All soils showed an increase in yield above the $56 \mathrm{~kg} \mathrm{ha}^{-1}$ rate but only the Webster soil showed a positive relationship to increasing $\mathrm{N}$ above this rate (Fig. 5). These results show that soils with a higher water holding capacity (Webster) had a different response to $\mathrm{N}$ compared to soils with lower water holding capacity (Clarion, Canisteo). Even though the studies were conducted at a different location, the soils were similar to those in these $\mathrm{N}$ studies so these results help explain the results shown in Fig. 4. The lack of response to $\mathrm{N}$ across the majority of the fields was related to the distribution of soils within the field. The Sac Field, in 2000, had a decrease in yield with increasing $\mathrm{N}$ was caused by the large amount of highly eroded Clarion soils within the field resulting in a limitation on the water holding capacity in the soil profile causing yields to be severely limited by water. These results are similar to those reported by Massey et al. (2008) in which the eroded soils had the lower yields and in this study lower yields were associated with soils having lower water holding capacity. Similar findings were reported by Sadler et al. (2000b) in which they suggested that understanding of site-specific yield maps would be enhanced by observations of water stress within the field. Their observations and those from this study suggest that spatial yield patterns in response to $\mathrm{N}$ management are dictated by soil types within the field and the interaction with soil water availability.

In order to understand the spatial patterns of yield within a strip, a stepwise approach was taken to evaluate these patterns. The first step was to evaluate the frequency distribution of yields for the different $\mathrm{N}$ rates as shown for the Coon Rapids field (Fig. 6). These frequency distributions are similar to other fields in this study. In all fields, the lower $\mathrm{N}$ rate had a lower mean yield but a similar range of minimum and maximum yields compared to the other $\mathrm{N}$ rates; however, the distribution showed a wider dispersion and more variation. As the $\mathrm{N}$ rate increased the variation pattern showed reduced dispersion with a higher frequency of values near the mean value (134 kg ha-1 compared to $200 \mathrm{~kg} \mathrm{ha}^{-1}$ ). In all fields we observed that the higher the $\mathrm{N}$ rate the less variation in frequency distribution with a similar shape of the yield distribution and the range of maximum and minimum values. The distribution of the yields based on the percentiles showed the 134 and $200 \mathrm{~kg} \mathrm{ha}^{-1}$ rates were the same. All three rates showed a skewed distribution toward the lower yields.

To further evaluate the spatial patterns within fields, yields were summarized by each soil type within each field for $\mathrm{N}$ rates. Spatial variation of yields within fields was significant in their relationship to soil variation within the field. Across all of the $\mathrm{N}$ rates there was a similar pattern with the higher yields in the Webster soils and the lower yields in the Clarion soils (Fig. 7). Yields in the Webster soils were larger than the yields in the Clarion soils at all $\mathrm{N}$ rates and showed less variation than those in the Clarion soils (Fig. 7). This type of analysis was completed for all of the different fields evaluated in this study and the results shown in Fig. 7 were consistent among all of the fields with the soils having a higher water holding capacity producing the larger yields compared to those soils with lower water holding capacity.

When the yields are aggregated to create a $\mathrm{N}$ response curve across fields, yield differences were significant using a simple T-test between these two soils. These two soils were chosen because they were the most dominant in all of the different fields measured in this study. Yield differences between the Clarion and Webster soil at the 134 and $190 \mathrm{~kg} \mathrm{ha}^{-1}$ rates were over $1000 \mathrm{~kg} \mathrm{ha}^{-1}$ and there was a decrease in the corn yield with the $\mathrm{N}$ rate of $190 \mathrm{~kg} \mathrm{ha}^{-1}$ in 

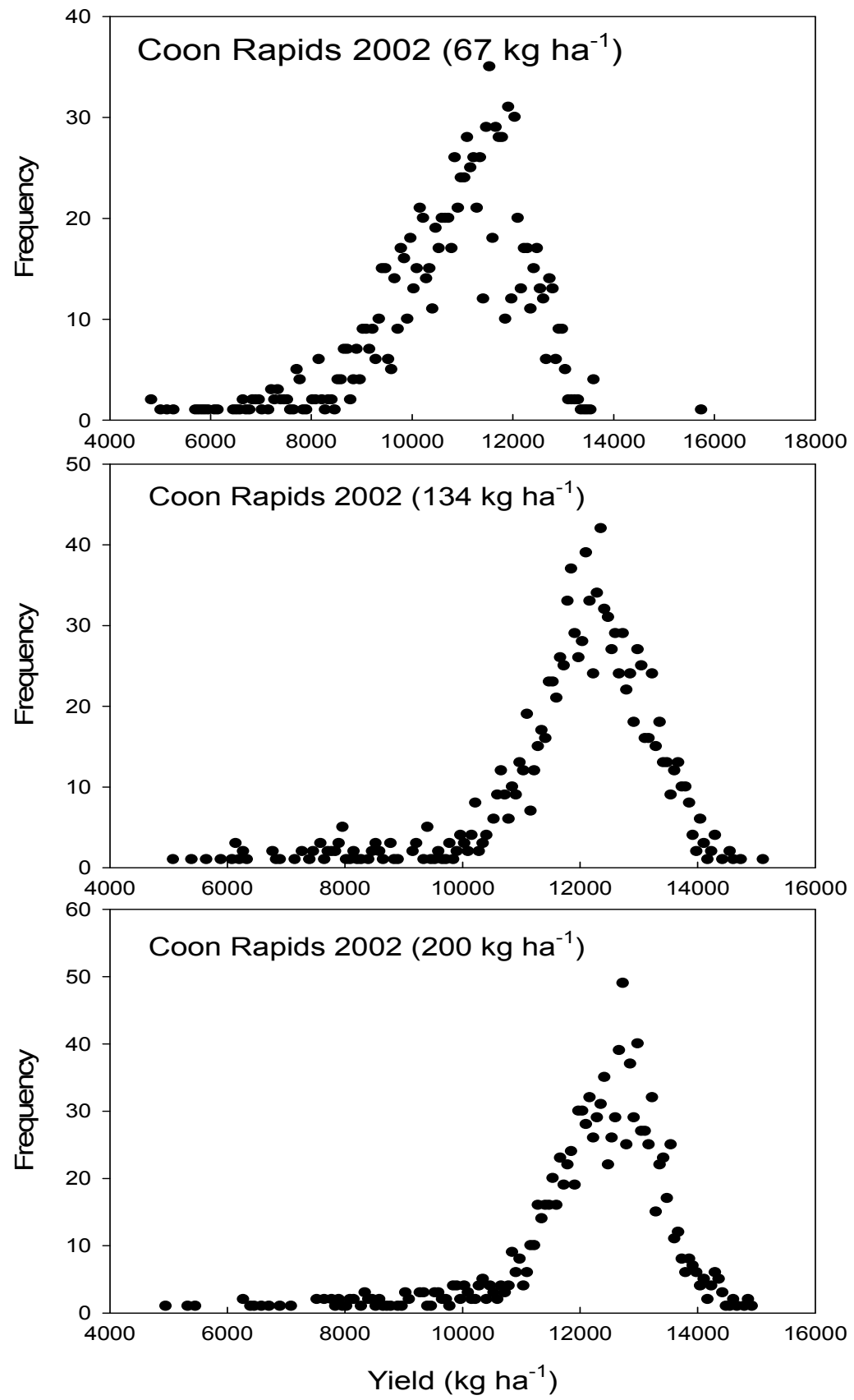

Fig. 6. Frequency distribution of corn yields at the 67,134 , and $200 \mathrm{~kg} \mathrm{~N} \mathrm{ha}^{-1}$ rate for the Coon Rapids field in 2002. 

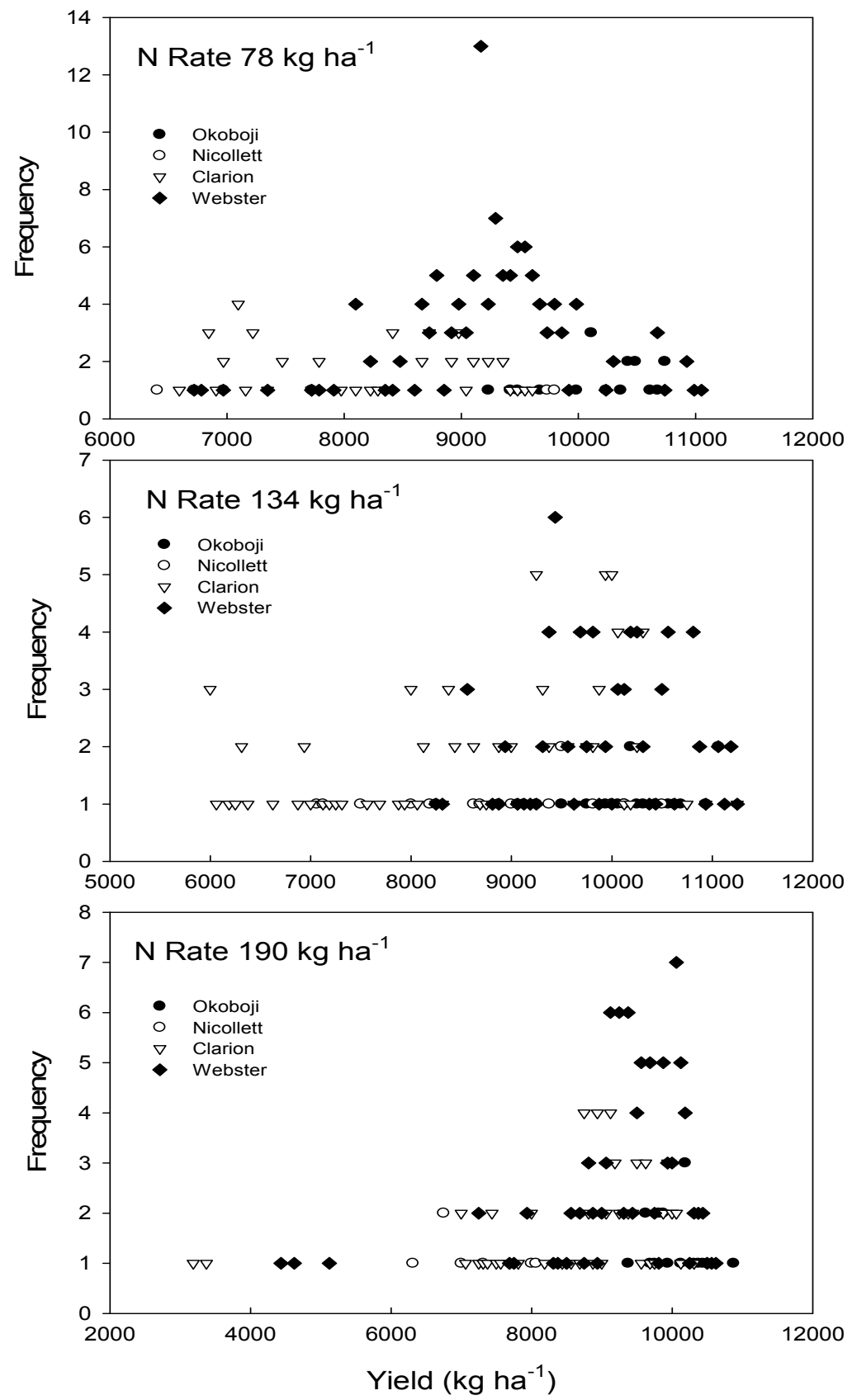

Fig. 7. Frequency distribution of corn yields for the 78, 134, and $190 \mathrm{~kg} \mathrm{~N} \mathrm{ha}{ }^{-1}$ rate for the four soil types within the field in the Calhoun East field in 2002. 
the Clarion soil (Fig. 8). This was a similar response as to that observed in the Sac field in 2000 (Fig. 4). The $\mathrm{N}$ response curve shown in Fig. 5 suggests that the improved water holding capacity of the Webster soil allows for enhanced yield compared to the other soils because of the increased available soil water during grain-filling. Seasonal water use patterns between a Clarion and Webster soil were significant during the reproductive stage of growth because at this time of the year, crop water use was dependent upon stored soil water in the soil profile (Fig. 2). These water use patterns lead to differences in crop water stress which affects yield patterns as suggested by Sadler et al. (2000b). This was a consistent finding across all of the fields examined in this study in which the higher water holding capacity soils had a higher yield regardless of $\mathrm{N}$ rate. Observations from the $78 \mathrm{~kg}$

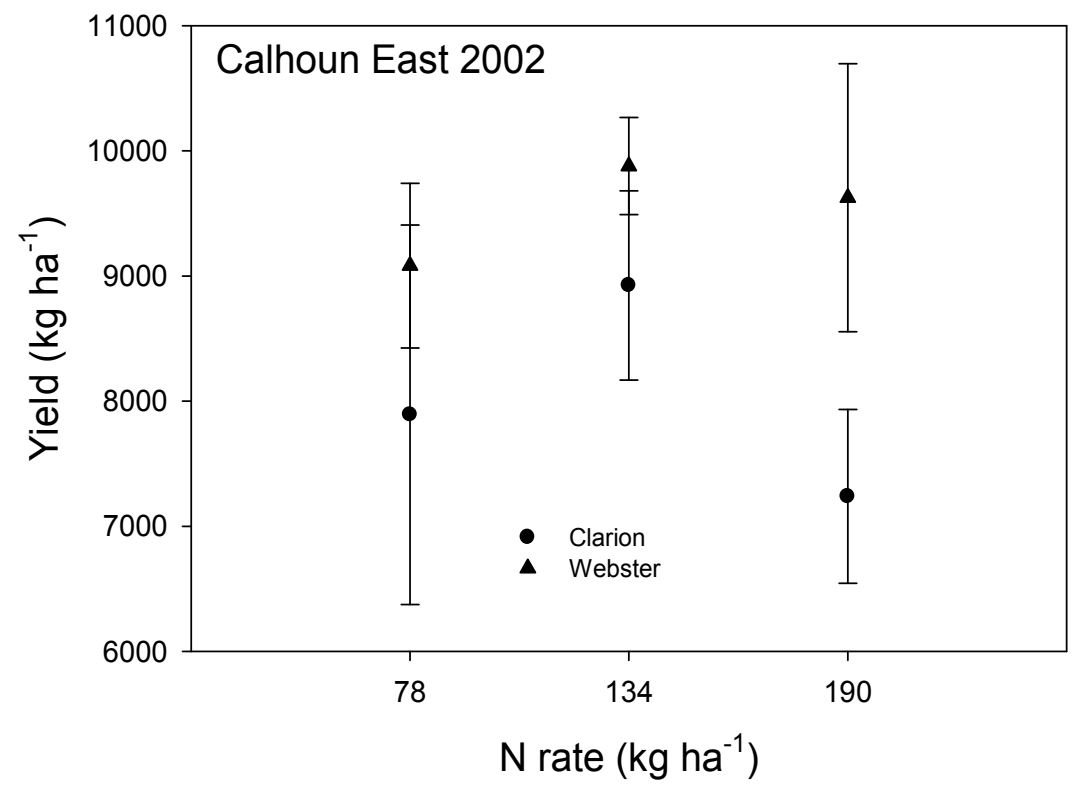

Fig. 8. Corn yield response to applied nitrogen for Clarion and Webster soils using three $\mathrm{N}$ rates in 2002.

$\mathrm{N}$ ha-1 ${ }^{-1}$ ate showed that yields in the Clarion soil were distributed across the range of yields observed in the field. There were changes in the statistical moments for the yields in the different soils within $\mathrm{N}$ rates as shown in Table 3. Yields in the 134 and $190 \mathrm{~kg} \mathrm{~N}^{-1} \mathrm{rate}^{-}$ were not significantly different for any of soils (Table 4). The yield distribution within the soil types reveals the effects of the soil water availability as a major factor in determining yield response to $\mathrm{N}$ rates (Fig. 7). Evaluation of the $\mathrm{N}$ response across fields will have to account for the water holding capacity of the soil and the precipitation during the growing season in order to interpret the results. Analysis of the yield distributions within fields segregated by soil type demonstrates the impact that available soil water has on determining the spatial pattern of corn yield. 


\begin{tabular}{|l|c|c|c|c|c|}
\hline Soil Type & N Rate & Mean & Std. Dev. & Skewness & Kurtosis \\
\hline \multirow{4}{*}{ Clarion } & 78 & 129.9 & 14.8 & -0.09 & -1.46 \\
\cline { 2 - 6 } & 134 & 140.6 & 21.6 & -0.59 & -0.65 \\
\cline { 2 - 6 } & 190 & 140.8 & 20.7 & -2.29 & 7.63 \\
\hline \multirow{4}{*}{ Nicollett } & 78 & 124.5 & 22.5 & 0.65 & -1.72 \\
\cline { 2 - 6 } & 134 & 143.2 & 15.9 & -0.37 & -0.49 \\
\cline { 2 - 6 } & 190 & 114.7 & 10.6 & 0.41 & -1.21 \\
\hline \multirow{3}{*}{ Webster } & 78 & 147.0 & 12.3 & -0.50 & 1.62 \\
\cline { 2 - 6 } & 134 & 158.8 & 11.5 & -0.21 & -0.48 \\
\hline & 190 & 149.2 & 16.9 & -2.55 & 8.80 \\
\cline { 2 - 6 } & 13 & 162.2 & 7.4 & -7.7 & -0.42 \\
\cline { 2 - 6 } & 190 & 165.4 & 6.9 & 0.08 & 0.35 \\
\hline
\end{tabular}

Table 4. Mean, standard deviation, skewness, and kurtosis for corn yields within each soil type for different $\mathrm{N}$ rates within the Calhoun East field in 2002.

\subsection{Seasonal patterns in fields}

Harvested yield represents one point in the season which is the result of all of the interacting factors during the season. One question is whether the factors that affect yield patterns at harvest persist throughout the growing season or are there changes which occur and are detectable only in grain yield. Application of techniques related to improved management decisions require that observations within a field be able to detect a plant response that is ultimately related to crop yield as part of the decision making process. Sadler et al. (2000b) suggested that yield patterns could be explained by following the patterns of crop stress during the season. These data sets contain a sequence of measurements during the growing season that may be related to crop yield. The hyperspectral remote sensing data allowed for several indices to be calculated; however, one of the relationships we examined was the red $(0.681 \mu \mathrm{m}) /$ green $(0.561 \mu \mathrm{m})$ ratio. This ratio was selected because of the strong relationship to crop biomass and crop yield. There was an inverse relationship between yield and the August red/green index for the fields (Fig. 9). Although there was a large variation about the regression line, this index showed a significant relationship with yield compared to other vegetative indices. Seasonal patterns of different vegetative indices provide insights into the spatial patterns of vegetative response during the course of the growing season. In this study we evaluated the NIR $(0.819 \mu \mathrm{m})$ / red $(0.681 \mu \mathrm{m})$ ratio and found that this vegetative index was not consistently related to yield across all of the fields while the red/green relationship showed a more consistent relationship across all of the fields. There are large varieties of vegetative indices that can be computed from the wavebands shown in Table 2; however, the consistency of this index across the fields in this study was one of the primary reasons for its use in these analyses. Hatfield et al. (2008) reviewed the different indices derived from remote sensing signals and their relationship to various agronomic variables and there are a variety of different indices which can be applied to these fields and in this study the red/green index provided a useful method of assessing response across fields. 


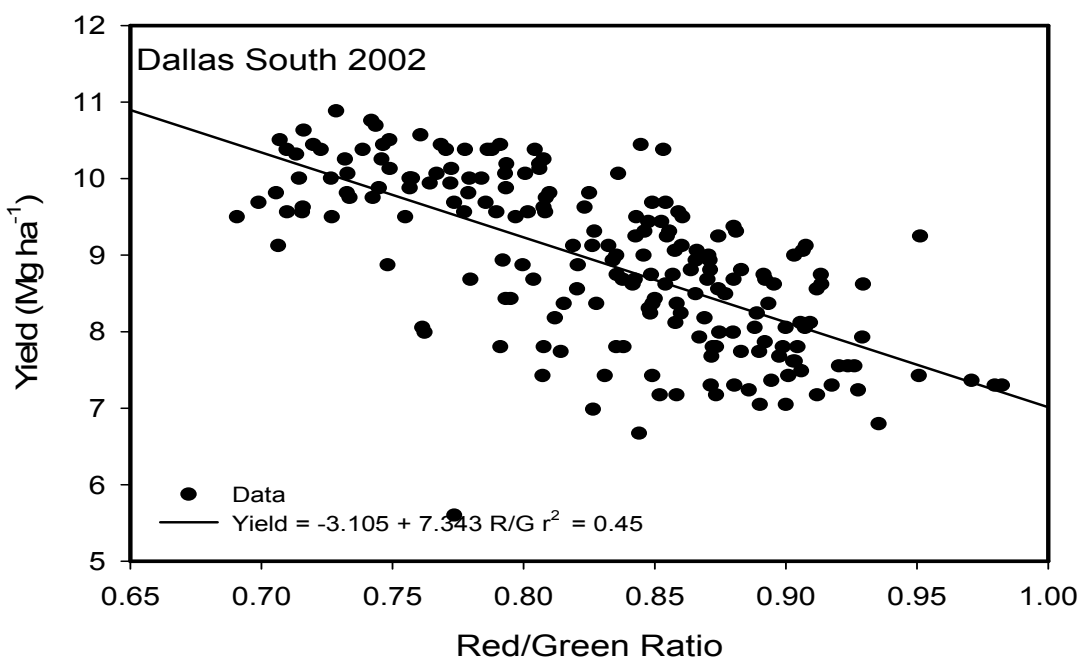

Fig. 9. Relationship between corn yield and red/green ratio observed in August with an aircraft scanner for the Dallas South field in 2002.

A more detailed examination of the red/green ratio was conducted with the observations collected four times during the growing season. Observations throughout the season represent unique characteristics of the growing season, May observations represent the soil background, July represents maximum vegetative cover, August the point of mid-grain fill, and September the time near physiological maturity (Fig. 10). At each of these times the frequency distribution of the red/green ratio was computed for each $\mathrm{N}$ rate within the field. There is a seasonal trend in the frequency distributions with a decrease in the variation found in the distribution from the May to July or August observations and then an increase in variation for the September observations (Fig. 10). Variation in the red/green ratios early in the season was related to the soil variation within each $\mathrm{N}$ rate. The variation in the July and August observations was small for all three $\mathrm{N}$ rates. Observations of the water use patterns among soils within a field showed little difference at this time of the growing season because there was adequate soil water in all soils to meet crop demands. Later in the growing season the crop water demand exceeds the precipitation and crop water use is dependent upon stored soil water and variation among soils becomes evident and the variation in the red/green ratio is similar to the bare soil distribution (Fig. 10). There was no significant difference among the 67, 134, or $200 \mathrm{~kg} \mathrm{~N} \mathrm{ha}^{-1}$ rates for the frequency distributions of the red/green ratio (Fig. 10). The frequency patterns of the red/green ratios within $\mathrm{N}$ rates follow the yield patterns. Spatial patterns of reflectance reveal the seasonal dynamics of the interactions of soil types with $\mathrm{N}$ rates. These same patterns of red/green reflectance throughout the season were the same across all of the fields within this study. There is a consistent pattern in terms of a decreasing variation as the crop develops until mid-grain fill and then variation increases during the later grain-fill stages. The only difference among fields was whether the early grain-fill observations began to reveal spatial variation because of the lack of soil water in the profile and limited precipitation to meet the crop water demands. In fields with adequate soil water during grain-fill the variation is less pronounced. 

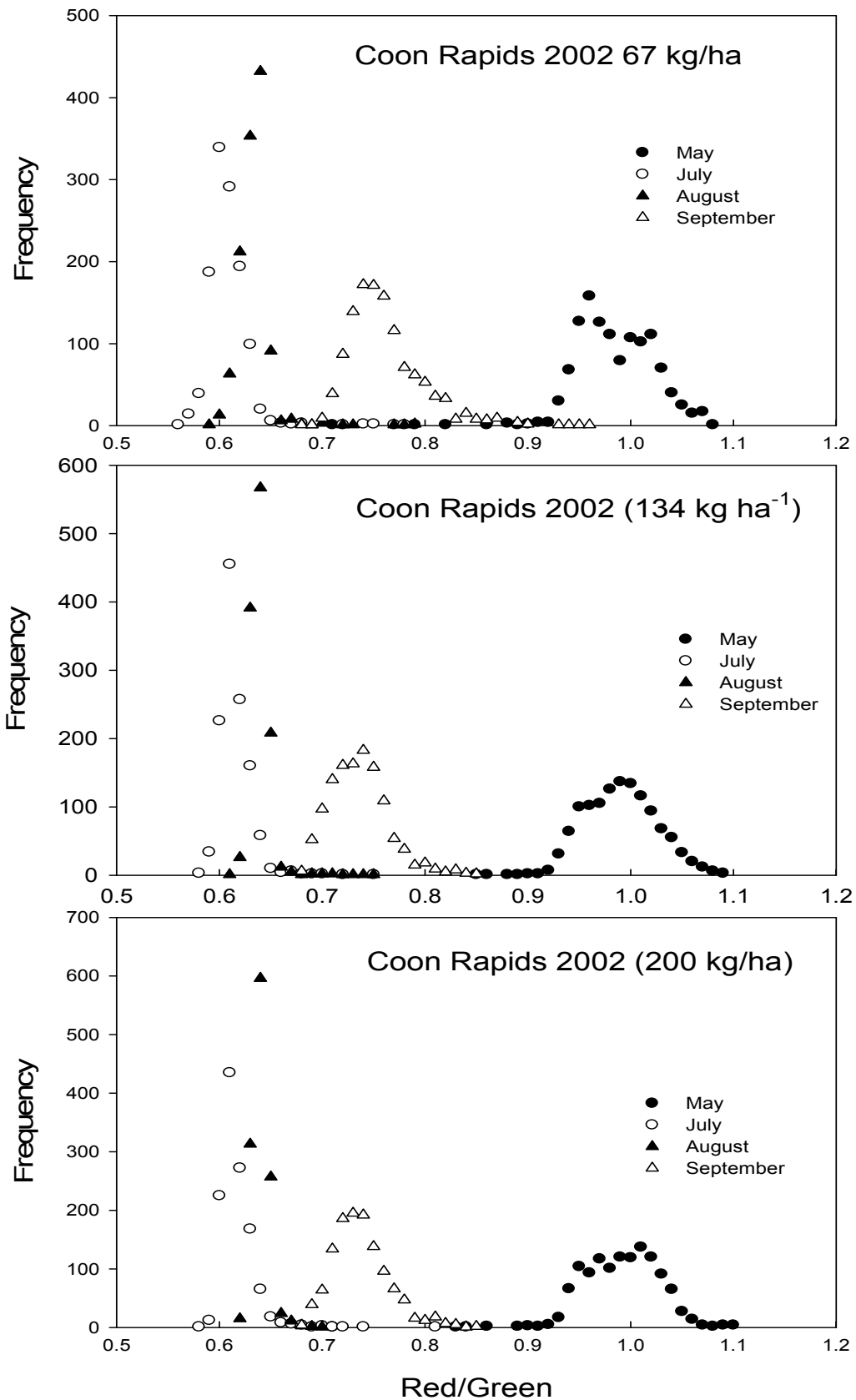

Fig. 10. Frequency distribution of red/green ratio for the four observation times during the 2002 growing season for the Coon Rapids field with 67, 134, and $200 \mathrm{~kg} \mathrm{~N}^{-1}$ rate. 
Spatial analysis of the red/green index for the May and August periods during the 2002 growing season showed the effect of the soil differences for the May image with the differences from west to east that were related to the distribution of soil types within the field (Fig. 11). The presence of waterway was very evident in this kriged map of the field. The range of the samples was $20 \mathrm{~m}$ indicating there were detectable differences over relatively short distances within the field. In other fields the range was considerably longer and on the order of 80 to $100 \mathrm{~m}$. Spatial analysis was able to reveal the patterns of the soil types within the fields. This is in contrast with August image in which there is little variation across the field in the red/green ratio (Fig. 12). There is one spot with poor plant growth that was detectable in the field. In this analysis there was no stable range in the data because there were no significant spatial patterns detected within the field. These interpolated maps confirm the analysis conducted within each strip that showed the July and August periods have the least variation in vegetative indices across the field because the crop growth is uniform (Fig. 12). The growth of the crop reduces the variation within the field and there is no detectable variation caused by the $\mathrm{N}$ rates within this field. Spatial analysis of the September red/green ratios showed the variation had reoccurred within the field (Fig. 13). This temporal pattern was common across all of the fields in which the variation in the red/green ratio decreased in the July and August observations and there was no correlation of these ratios with soil types within the field. The reason for this pattern is that during this phase of crop growth the water use rate is small and with the soil profile completely recharged at the beginning of the growing season there is more than sufficient soil water along with the precipitation to produce a uniform growth across the field. During the grain-fill period when crop water use rates are larger and precipitation is more infrequent then soil water availability from the soil profile becomes a critical factor and influences the red/green ratio because of the effect on leaf senescence.
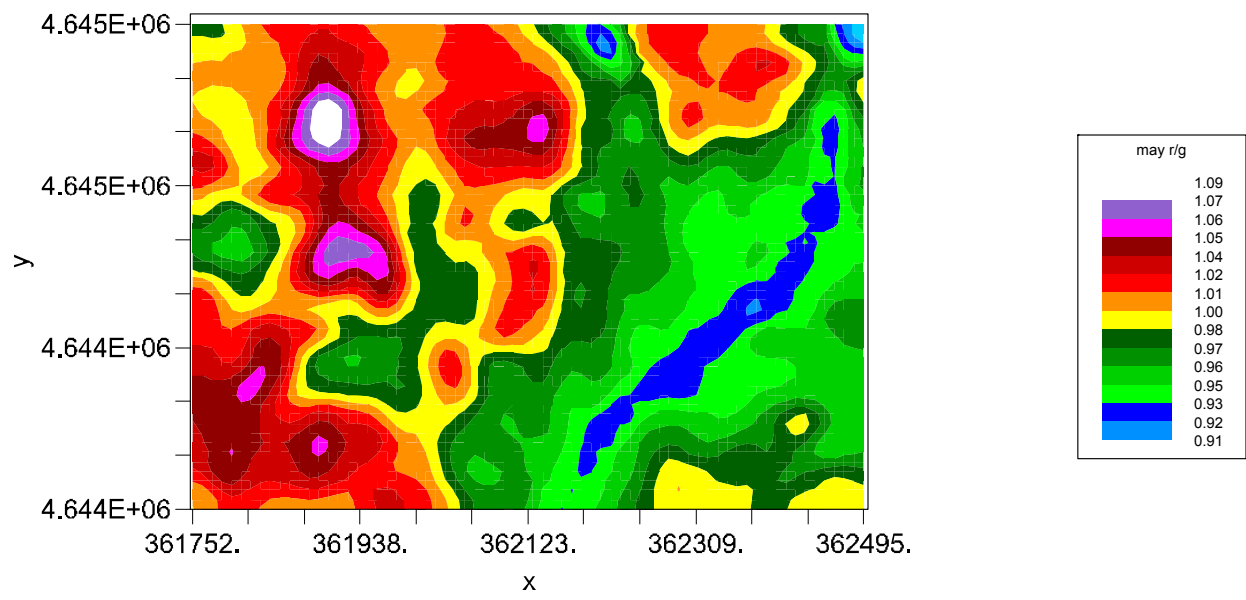

Fig. 11. Spatial map of the red/green ratio for the Coon Rapids field in 2002 for the May image. 

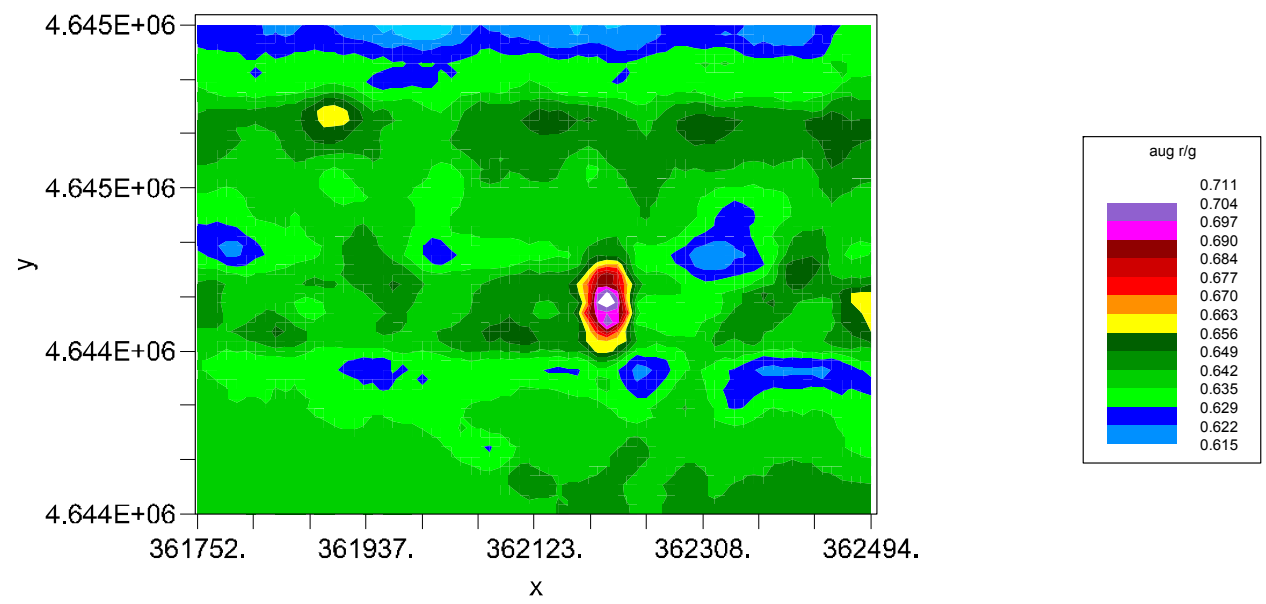

Fig. 12. Spatial map of the red/green ratio for the Coon Rapids field in 2002 for the August image.
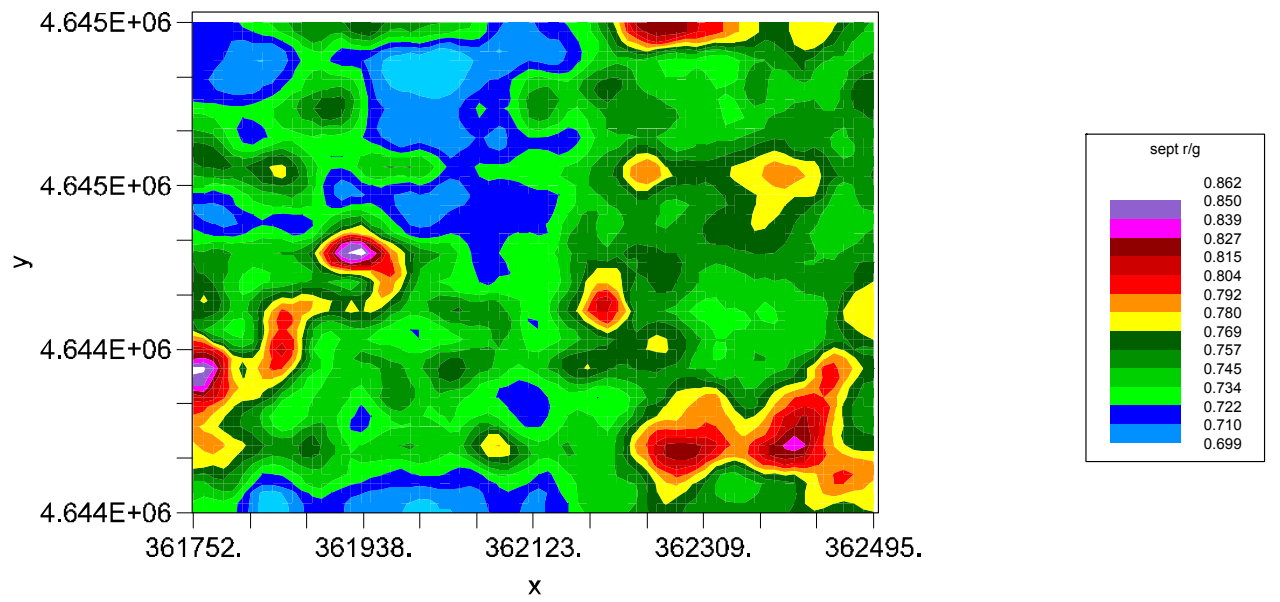

Fig. 13. Spatial map of the red/green ratio for the Coon Rapids field in 2002 for the September image.

Spatial variation maps for the Coon Rapids field in 2002 showed the yield variation patterns that indicated evidence of a relationship to $\mathrm{N}$ rates at the higher $\mathrm{N}$ rate of $200 \mathrm{~kg} \mathrm{ha}^{-1}$. The May spatial analysis image had a significant correlation with the yield of 0.65 . These strips had higher yields in parts of the field but were not consistent across the entire strip and there was a difference between the west and east end of the field (Fig. 14). The September red/green patterns were significantly correlated with the May red/green values with a 
value of 0.70 and are indicative of the role of soil variation and the effect on soil water dominating the effect of $\mathrm{N}$. The higher yields were found in the Webster soils as shown earlier with the frequency distribution of yields. The spatial map of yields show these high yields but the high yields are not consistent with $\mathrm{N}$ rates. There was the reemergence of the presence of the waterway within the field in the yield map that was present in the May spatial map of the field. These patterns within fields were found in the other fields we examined in this study and there was a significant correlation between the yield and soil type across all fields of 0.58 . The growing season conditions during these study years had normal or slightly below normal precipitation amounts during the growing season and above normal precipitation during grain fill would offset these relationships and allow for more potential benefit of applied N. This finding confirms the observations from Jaynes and Colvin (1997) in which the spatial variation of yield was related to seasonal precipitation and extends their results to include the interacting effects of $\mathrm{N}$ management.
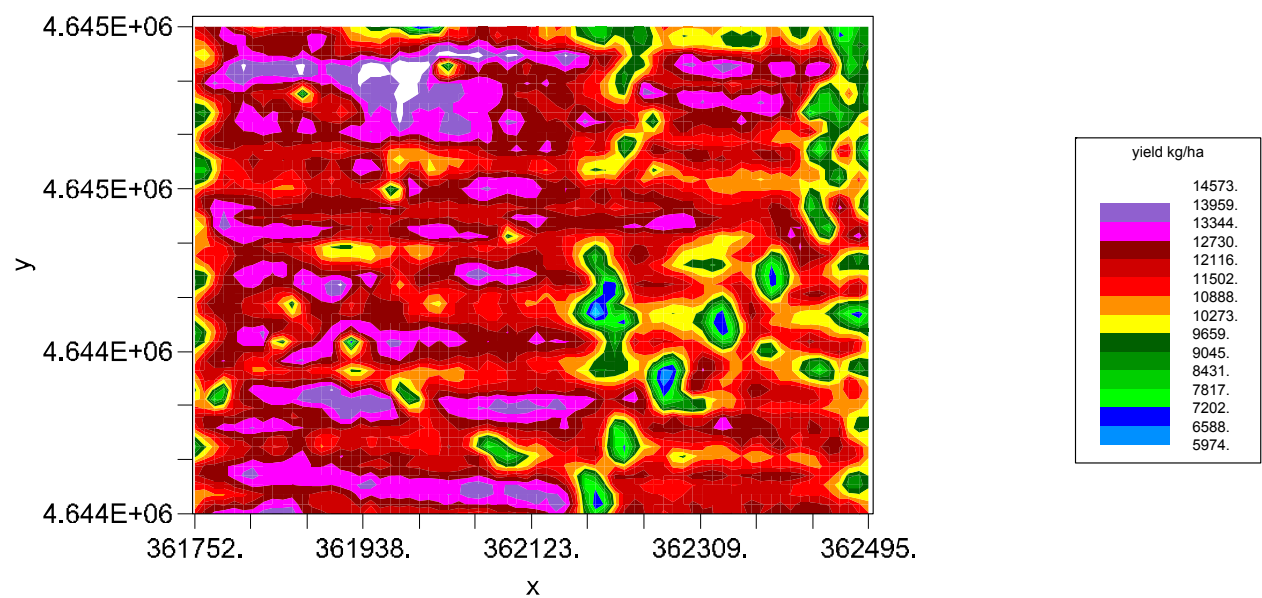

Fig. 14. Interpolated yield map from the Coon Rapids field in 2002 using spatial analysis software.

\section{Conclusions}

Nitrogen response across agricultural fields is more complex than observing a consistent response across a change in management practices. Observations among fields has shown that when multiple soils are encountered within a production field there are spatial patterns in both water use and $\mathrm{N}$ impacts on crop yield. There have been few studies which have coupled water and $\mathrm{N}$ dynamics across corn production fields. It has been assumed that water patterns operate separately from $\mathrm{N}$ management practices; however, the spatial patterns within a field show there is a temporal and spatial pattern determined by the combination of the precipitation patterns during the season, the soil water holding capacity, and the crop growth (crop water use) patterns. Observations of $\mathrm{N}$ impacts on corn yield across production scale fields revealed that yield responses were dependent upon the soil type and within a rate strip there were a range of yields and when further dissected into the 
spatial patterns, these spatial patterns were related to the water use patterns and soil water holding capacity. The observations from this study revealed that $\mathrm{N}$ impacts on crop yield were directly related to soil water holding capacity and to improve $\mathrm{N}$ response an improvement in soil water availability during grain-filling would be necessary.

Observations of the changes in the spatial patterns during the growing season have shown that there is complex interaction between the patterns of soil within the field and the final pattern of corn yield as a function of the patterns of soil water use and $\mathrm{N}$ management inputs. Agriculture will benefit from an enhanced understanding of the interactions of soil water use and $\mathrm{N}$ management and how these interact across a production field. The combination of remote sensing along with yield maps offers an enhanced method to evaluate field scale responses to both weather and management which will benefit production efficiency. These efforts will lead toward improved production efficiency and enhance the capability of agricultural systems to become more efficient in terms of water and $\mathrm{N}$ use.

\section{Acknowledgements}

The support of the Risk Management Agency and especially Virginia Guzman and Dave Fulk are greatly acknowledged and this research is under the agreement 07-IA-0831-0210. This effort would not be possible without the capable support of Brooks Engelhardt, Wolf Oesterreich, and Bert Swalla in their efforts to collect and process the data from the field experiments and the interactions with Galen Hart for his encouragement and insights. Likewise, the support of the producers Don Ferguson, Mike Hermanson, Nels Leo, Kriss Lightener, Dale Pennington, and David Schroeder who willingly let us use their fields for these studies and the efforts of the Farnhamville Cooperative of Farnhamville, IA (Jeff True, Gabe Tar) for helping identify the producers. The support from CALMIT at the University of Nebraska (Rich Perk and Don Rundquist) to obtain the hyperspectral data is greatly appreciated.

\section{References}

Blackmer, T.M., Schepers, J.S. (1996). Aerial photography to detect nitrogen stress in corn. J. Plant Physiol. 148:440-444.

Blackmer, T.M., Schepers, J.S., Varvel, G.E. (1994). Light reflectance compared with other nitrogen stress measurements in corn leaves Agron. J. 86:934-938.

Blackmer, T.M., Schepers, J.S., Varvel, G.E., Meyer, G.E. (1996a). Analysis of aerial photography for nitrogen stress within corn fields. Agron. J. 88:729-733.

Blackmer, T.M., Schepers, J.S., Varvel, G.E., Walter-Shea, E.A. (1996b). Nitrogen deficiency detection using reflected shortwave radiation from irrigated corn canopies. Agron. J. 88:1-5.

Blackmer, T.M., Schepers, J.S., Vigil, M.F. (1993). Chlorophyll meter readings in corn as affected by plant spacing. Commun. Soil Sci. Plant Anal. 24:2507-2516.

Brock, A., Brouder, S.M., Blumhoff, G., Hoffman, B.S. (2005). Defining yield-based management zones for corn-soybean rotations. Agron. J. 97:1115-1128.

Brouder, S.M., Mengel, D.B., Hoffman, B.S. (2000). Diagnostic efficiency of the black layer stalk nitrate and grain nitrogen tests for maize. Agron. J. 92:1236-1247.

Burkart, M.R., James. D.E. (1999). Agricultural nitrogen contributions to hypoxia in the Gulf of Mexico. J. Environ. Qual. 28:850-859. 
Chen, P., Haboudane, D., Trembaly, N., Wang, J., Vigneault, P., Li, B. (2010). New spectral indicator assessing the efficiency of crop nitrogen treatment in corn and wheat. Remote Sens. Environ. 114:1987-1997.

Haboudane, D., Miller, J.R., Trembaly, N., Zarco-Tejada, P.J., Dextraze, L. (2002). Integrated narrow-band vegetation indices for prediction of crop chlorophyll content for application to precision agriculture. Remote Sens. Environ. 81:416-426.

Hatfield, J.L., Prueger, J.H. (2001). Increasing nitrogen use efficiency of corn in Midwestern cropping systems. Proceedings of the $2^{\text {nd }}$ International Nitrogen Conference on Science and Policy. TheScientificWorld (2001) 1(S2):682-690.

Hatfield, J.L., Jaynes, D.B., Burkart, M.R., Cambardella, C.A., Moorman, T.B., Prueger, J.H., Smith, M.A. (1999). Water quality in Walnut Creek watershed: Setting and farming practices. J. Environ. Qual. 28:11-24.

Hatfield, J.L., Prueger, J.H., Kustas, W.P. (2007). Spatial and temporal variation of energy and carbon dioxide fluxes in corn and soybean fields in central Iowa. Agron. J. 99:285-296.

Hatfield, J.L., Gitelson, A.A., Schepers, J.S., and Walthall, C.L. (2008). Application of Spectral Remote Sensing for Agronomic Decisions. Agron. J. 100:S-117-S-131.

Hatfield, J.L., McMullen, L.D., Jones, C.W. (2009). Nitrate-nitrogen patterns in the Raccoon River Basin as related to agricultural practices. J. Soil and Water Conserv. 64:190-199.

Hernandez-Ramirez, G., Hatfield, J.L., Prueger, J.H., and Sauer, T.J. (2010). Energy balance and turbulent flux partitioning in a corn-soybean rotation in the Midwestern U.S. Theor. Appl. Climatol. 100:79-92.

Jaynes, D.B., Colvin. T.S. (1997). Spatiotemporal variability of corn and soybean yield. Agron. J. 89:30-37.

Jaynes, D.B., Hatfield, J.L., Meek, D.W. (1999). Water Quality in Walnut Creek Watershed: Herbicides and Nitrate in Surface Waters. J. Environ. Qual. 28:45-59.

Jaynes, D.B, Colvin, T.S., Karlen, D.L., Cambardella, C.A., Meek, D.W. (2001). Nitrate loss in subsurface drainage as affected by nitrogen fertilizer rate. J. Environ. Qual. 30:1305-1314.

Inman, D., Khosla, R., Reich, R., Westfall, D.G. (2008). Normalized difference vegetation index and soil color-based management zones in irrigated maize. Agron. J. 100:60-66.

Lee, Y., Yang, C., Chang, K., Shen, Y. (2008). A simple spectral index using reflectance of 735 $\mathrm{nm}$ to assess nitrogen status of rice canopy. Agron. J. 100:205-212.

Massey, R.E., Myers, D.B., Kitchen, N.R., Sudduth, K.A. (2008). Profitability maps as an input for site-specific management decision making. Agron. J. 100:52-59.

Ritchie, J.T., Burnett. E. (1971). Dryland evaporative flux in a subhumid climate: II. Plant influences. Agron. J. 63:56-62.

Sadler, E.J., Bauer, P.J., Busscher, W.J. (2000a). Site-specific analysis of a droughted corn crop: I. Growth and grain yield. Agron. J. 92:395-402.

Sadler, E.J., Bauer, P.J., Busscher, W.J., Miller, J.A. (2000b). Site-specific analysis of a droughted corn crop: II. Water use and stress. Agron. J. 92:403-410.

SAS Institute (2009) User's guide. Statistics. Version 9, SAS Institute, Cary, North Carolina.

Schepers, J.S., Blackmer, T.M., Wilhelm, W.W., Resende, M. (1996). Transmittance and reflectance measurements of corn leaves from plants with different nitrogen and water supply. J. Plant Physiol. 148:523-529.

Schepers, J.S., Francis, D.D., Vigil, M., Below, F.E. (1992). Comparison of corn leaf nitrogen concentration and chlorophyll meter readings. Commun. Soil Sci. Plant Anal. 23:2173-2187. 


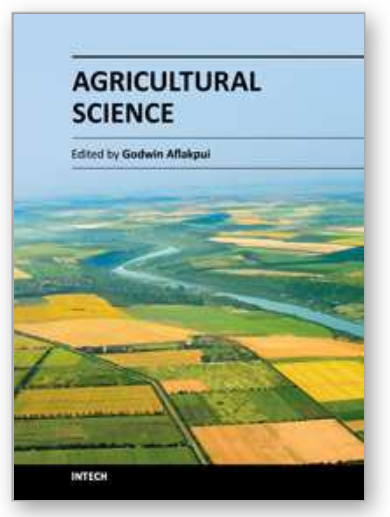

\author{
Agricultural Science \\ Edited by Dr. Godwin Aflakpui
}

ISBN 978-953-51-0567-1

Hard cover, 252 pages

Publisher InTech

Published online 27, April, 2012

Published in print edition April, 2012

This book covers key areas in agricultural science, namely crop improvement, production, response to water, nutrients, and temperature, crop protection, agriculture and human health, and animal nutrition. The contributions by the authors include manipulation of the variables and genetic resources of inheritance of quantitative genes, crop rotation, soil water and nitrogen, and effect of temperature on flowering. The rest are protecting crops against insect pests and diseases, linking agriculture landscape to recreation by humans, and small ruminant nutrition. This book is a valuable addition to the existing knowledge and is especially intended for university students and all professionals in the field of agriculture.

\title{
How to reference
}

In order to correctly reference this scholarly work, feel free to copy and paste the following:

Jerry L. Hatfield (2012). Spatial Patterns of Water and Nitrogen Response Within Corn Production Fields, Agricultural Science, Dr. Godwin Aflakpui (Ed.), ISBN: 978-953-51-0567-1, InTech, Available from: http://www.intechopen.com/books/agricultural-science/spatial-patterns-of-water-and-nitrogen-response-withincorn-production-fields

\section{INTECH}

open science | open minds

\section{InTech Europe}

University Campus STeP Ri Slavka Krautzeka 83/A 51000 Rijeka, Croatia Phone: +385 (51) 770447

Fax: +385 (51) 686166 www.intechopen.com

\section{InTech China}

Unit 405, Office Block, Hotel Equatorial Shanghai No.65, Yan An Road (West), Shanghai, 200040, China 中国上海市延安西路65号上海国际贵都大饭店办公楼405单元 Phone: +86-21-62489820

Fax: +86-21-62489821 
(C) 2012 The Author(s). Licensee IntechOpen. This is an open access article distributed under the terms of the Creative Commons Attribution 3.0 License, which permits unrestricted use, distribution, and reproduction in any medium, provided the original work is properly cited. 